\title{
PERANAN ASPEK EKONOMIS PARIWISATA KOTA BOGOR TERHADAP PENDAPATAN ASLI DAERAH
}

\author{
Dina Mayasari ${ }^{1}$, Sekti Rahardjo $^{2}$ \\ ${ }^{1}$ Manajemen Perhotelan, Sekolah Tinggi Pariwisata Bogor, dinamayasari3@gmail.com \\ ${ }^{2}$ Manajemen Perhotelan, Sekolah Tinggi Pariwisata Bogor, sektirahardjo@gmail.com
}

\begin{abstract}
ABSTRAK:
Penelitian ini bertujuan untuk mengkaji peranan aspek ekonomis pariwisata Kota Bogor terhadap Pendapatan Asli Daerah (PAD), melalui kontribusi Pajak Hotel, Pajak Restoran dan Pajak Hiburan Kota Bogor yang dibatasi dalam kurun waktu 2007-2017. Tujuan lainnya adalah untuk mengetahui adakah pengaruh dari masing masing pajak usaha pariwisata tersebut terhadap PAD serta manakah yang paling dominan pengaruhnya. Metode penelitian yang digunakan adalah pendekatan kuantitatif dengan teknik analisis data yaitu analisis kontribusi dan analisis regresi linear sederhana. Pengumpulan data didapat dari data sekunder dokumentasi dari Badan Pendapatan Daerah dan Dinas Pariwisata Kota Bogor, juga dari studi literatur. Hasil yang didapat adalah rasio kontribusi pajak sektor pariwisata Kota Bogor terhadap PAD dalam kurun waktu 2007-2017 adalah sebesar 25.62\% sehingga dapat dikategorikan dalam kriteria sedang. Pajak Hotel, Pajak Restoran dan Pajak Hiburan Kota Bogor secara parsial berpengaruh positif dan signifikan terhadap PAD, sedangkan variabel yang paling dominan pengaruhnya adalah Pajak Restoran.
\end{abstract}

Kata Kunci: Pajak Hotel, Pajak Restoran, Pajak Hiburan, Peranan Ekonomis,PAD Kota Bogor

\section{ABSTRACT:}

This study aims to examine the role of the economic aspect of Bogor City tourism on Local Revenue (PAD), through the contribution of Hotel Taxes, Restaurant Taxes and Entertainment Taxes in Bogor City which are restricted in the period 2007-2017. Another goal is to find out whether there is an influence of each of the tourism business taxes on PAD and which is the most dominant influence. The research method used is a quantitative approach with data analysis techniques namely contribution analysis and simple linear regression analysis. Data collection was obtained from secondary data documentation from the Bogor City Regional Revenue and Tourism Agency, as well as from literature studies. The results obtained are the contribution ratio of the Bogor tourism sector to the PAD in the period 2007-2017 is $25.62 \%$ so that it can be categorized in the medium criteria. Hotel Tax, Restaurant Tax and Entertainment Tax in Bogor City partially have a positive and significant effect on PAD, while the most dominant variable is Restaurant Tax.

Keywords: Hotel Tax, Restaurant Tax, Entertainment Tax, Economic Role, PAD Bogor City. 


\section{National Conference of Creative Industry: \\ Sustainable Tourism Industry for Economic Development}

Universitas Bunda Mulia, Jakarta, 5-6 September 2018

e-ISSN No: 2622-7436

\section{PENDAHULUAN}

Pariwisata merupakan salah satu jenis industri baru yang mampu menghasilkan pertumbuhan ekonomi yang cepat dalam penyediaan lapangan kerja, standar hidup serta menstimulasi sektor-sektor produktivitas lainnya(Wahab, 2006).Menurut Spillane (1987),peranan pariwisata dalam pembangunan negara pada garis besarnya berintikan tiga segi, yaitu segi ekonomis seperti sumber devisa dan pajak, segi sosial dalam hal penyerapan tenaga kerja, dan segi kebudayaan dalam memperkenalkan kebudayaan daerah kepada wisatawan asing. Dalam peranannya dari segi ekonomis sebagai sumber devisa , pariwisata Indonesia terus menunjukan pertumbuhan yang signifikan dimana pada tahun 2016 menjadi sumber penghasil devisa negara di posisi kedua terbesar dan bahkan diproyeksikan pada tahun 2019 menjadi penyumbang terbesar devisa Indonesia yaitu US\$ 20 Milyar (Arief Yahya, 2018). Aspek ekonomi pariwisata berhubungan dengan kegiatan ekonomi yang langsung berkaitan dengan kegiatan pariwisata, seperti usaha perhotelan, usaha restoran dan rumah makan, usaha hiburan, transportasi, bisnis cendera mata, dan lainnya. Dalam penelitian sebelumnya Dina M.Soeswoyo (2018) menguraikan bahwa sektor pariwisata Kota Bogor yang berkontribusi terhadap Pajak Daerah dan Pendapatan Asli Daerah (PAD) hanya diperhitungkan dari Pajak Hotel, Pajak Restoran/rumah makan dan juga Pajak Hiburan, karena hanya dikelompokan dalam tiga (3) aspek tersebut. Pajak dari ketiga usaha sektor pariwisata Kota Bogor tersebut merupakan sumber penerimaan Pajak Daerah maupun Pendapatan Asli Daerah, kemudian menjadi komponen penting sumber dana dalam Anggaran Pendapatan dan Belanja Daerah (APBD) yang dipergunakan untuk keperluan pembangunan daerah Kota Bogor. Menurut Saepurrahman (2012), dari berbagai alternatif sumber penerimaan yang mungkin dipungut oleh daerah, Undang-Undang tentang Pemerintahan Daerah menetapkan Pajak Daerah menjadi salah satu sumber penerimaan yang berasal dari dalam daerah dan dapat dikembangkan sesuai dengan kondisi masing-masing daerah. Keberhasilan pertumbuhan sektor pariwisata Kota Bogor, akan mengakibatkan langsung terhadap peningkatkan pajak dari sektor pariwisata daerah dalam hal ini Pajak Hotel, Pajak Restoran dan Pajak Hiburan sehingga berpengaruh terhadap Pendapatan Asli Daerah (PAD) yang pada akhirnya dapat dimanfaatkan untuk berbagai biaya keperluan pemerintahan dan pengembangan daerahnya.

Kota Bogor yang berjarak sekitar $60 \mathrm{~km}$ dari Jakarta, merupakan salah satu kota penyangga Propinsi Jawa Barat. Disamping berbatasan langsung dengan Kota Jakarta sebagai Ibu-kota negara Indonesia yang juga merupakan pusat pemerintahan, Kota Bogor juga berbatasan langsung dengan Kota Depok, Tangerang dan Bekasi, sangat strategis dan mudah diakses dari berbagai arah baik melalui jalan raya biasa ataupun jalan bebas hambatan. Kota Bogor terkenal sebagai kota hujan dengan udaranya yang relatif terasa sejuk serta kaya akan berbagai daya tarik wisata alami, buatan dan budaya, sehingga banyak menarik banyak perhatian wisatawan nusantara dan juga wisatawan mancanegara. Perkembangan pariwisata Kota Bogor dapat dilihat dari bertambahnya berbagai amenitas dan daya tarik pariwisata. Berbagai fasilitas akomodasi, restoran juga tempat hiburan merupakan sarana penunjang yang diperlukan oleh wisatawan yang berkunjung ke Kota Bogor. Hal tersebut dapat dilihat dari banyaknya fasilitas akomodasi baik kelas hotel berbintang dan juga kelas hotel melati. Berbagai restoran dan rumah makan juga sangat mudah dijumpai baik rumah makan yang menyajikan macam-macam hidangan khas daerah Bogor, masakan khas daerah Indonesia lainnya maupun menu internasional. 
Tabel 1 -Jumlah Kunjungan Wisatawan Ke Kota Bogor

\begin{tabular}{cccc}
\hline Tahun & WISNUS & WISMAN & Total \\
2013 & $3,425,211$ & 167,006 & $3,592,217$ \\
2014 & $3,769,787$ & 183,807 & $3,953,594$ \\
2015 & $3,597,733$ & 202,108 & $3,799,841$ \\
2016 & $5,063,201$ & 246,870 & $5,310,071$ \\
2017 & $5,822,681$ & 283,901 & $6,106,582$ \\
Total & $13,725,777$ & 669,239 & $14,395,054$ \\
\hline
\end{tabular}

Sumber : Dinas Pariwisata \& Kebudayaan Kota Bogor, 2018

Pendapatan Asli Daerah (PAD) Pemerintah Kota Bogor didapat dari berbagai sumber diantaranya adalah dari pendapatan Pajak Daerah. Sektor Pariwisata Kota Bogor, melalui Pajak Hotel, Pajak Restoran/rumah makan dan Pajak Hiburan memberikan kontribusi dan pengaruh sebagai tiga komponen dari Pajak Daerah yang berkontribusi terhadap PAD Kota Bogor. Berikut adalah profil Pendapatan Asli Daerah Kota Bogor selama kurun waktu 11 tahun terakhir yaitu dari tahun anggaran 2007 sampai dengan tahun 2017 dapat dilihat pada Tabel 2 :

Tabel 2- Realisasi PenerimaanPajak Hotel,Restoran, Hiburan dan Pendapatan Asli Daerah (PAD)Kota Bogor, 2010-2017

\begin{tabular}{cccccc}
\hline Tahun & Pajak Hotel & Pajak Restoran & Pajak Hiburan & Total PAD & $\begin{array}{c}\text { Pertumbuhan } \\
\text { PAD(\%) }\end{array}$ \\
2007 & $3,299,162,210$ & $11,898,268,356$ & $1,738,596,597$ & $79,659,761,934$ & \\
2008 & $4,285,733,901$ & $14,188,920,460$ & $3,172,624,942$ & $97,730,780,727$ & 22.7 \\
2009 & $6,219,679,143$ & $18,798,189,871$ & $6,908,527,049$ & $115,921,660,827$ & 18.6 \\
2010 & $8,207,834,538$ & $23,342,416,373$ & $8,116,670,113$ & $127,488,089,831$ & 10 \\
2011 & $15,704,258,353$ & $27,252,802,195$ & $8,686,143,286$ & $230,449,644,620$ & 80,8 \\
2012 & $27,528,683,203$ & $39,510,789.644$ & $13,707,405,648$ & $252,280,722,686$ & 9,5 \\
2013 & $41,728,119,975$ & $50,035,057.749$ & $15,776,049,233$ & $300,932,470,210$ & 19.3 \\
2014 & $51,072,782,235$ & $59,965,768,360$ & $21,031,414,292$ & $483,014,420,704$ & 60,5 \\
2015 & $50,373,226,573$ & $75,128,975.542$ & $18,308,544,830$ & $627,815,080,243$ & 30 \\
2016 & $71,165,895,875$ & $95,415,220.190$ & $24,133,785,705$ & $728,030,823,933$ & 16 \\
2017 & $77,192,419,056$ & $110,306,908.127$ & $25,931,011,958$ & $977,803,906,993$ & 34.3 \\
\hline
\end{tabular}

Sumber: Badan Pendapatan Daerah Kota Bogor, 2018

Berdasarkan data pada Tabel 2, dapat diketahui bahwa nominal penerimaan PAD Kota Bogor selalu meningkat setiap tahunnya, namun bila dilihat dari tingkat pertumbuhannya mengalami prosentase kenaikan yang cukup berfluktuasi. Peningkatan 


\section{National Conference of Creative Industry: \\ Sustainable Tourism Industry for Economic Development}

Universitas Bunda Mulia, Jakarta, 5-6 September 2018 e-ISSN No: 2622-7436

Pendapatan Asli Daerah (PAD) dalam pembiayaan pembangunan tidak hanya penting dilihat dari nominal penerimaannya saja tetapi juga daritingkat pertumbuhannya.

Trend tingkat pertumbuhan realisasi penerimaan PAD dari sektor pariwisata Kota Bogor yang berfluktuasi, sangat menarik untuk dibuatkan suatu kajiankhusus untuk mengetahuiperanan aspek ekonomis pariwisata Kota Bogor dalam bentuk kontribusi Pajak Hotel , Pajak Restoran dan Pajak Hiburan terhadap PADdalam kurun waktu 2007-2017. Perlu juga dikaji pengaruhnya ketiga pajak usaha sektor pariwisata tersebutterhadap PAD Kota Bogor dalam kurun waktu yang sama, serta mengetahui pajak pariwisata mana yang paling dominan pengaruhnya.

Adapun tujuan dari penelitian ini adalah untuk mengetahui gambaran kontribusi segi ekonomis pariwisata Kota Bogor dalam hal ini adalah kontribusi pajak pariwisata dari Pajak Hotel, Pajak Restoran dan Pajak Hiburanterhadap Pendapatan Asli Daerah (PAD) Kota Bogor periode tahun 2007- 2017. Tujuan lainnya adalah untuk mengetahuiadanya pengaruh Pajak Hotel, Pajak Restoran dan Pajak Hiburan secara parsial terhadap PAD Kota Bogor pada kurun waktu yang sama dan juga mengetahui pengaruh yang paling dominan di antara ketiga pajak tersebut.

\section{TINJAUAN PUSTAKA}

\section{Pendapatan Asli Daerah (PAD)}

Undang-Undang Nomor 28 Tahun 2009 tentang Pajak Daerah dan Retribusi Daerahyang efektif berlaku mulai 1 Januari 2010, menyatakan bahwa Pendapatan Asli Daerah (PAD) adalah pendapatan yang diperoleh daerah yang dipungut berdasarkan peraturan daerah sesuai dengan peraturan perundang-undangan. Sumber PAD merupakan sumber keuangan daerah yang digali dalam wilayah daerah yang bersangkutan, yang terdiri dari: (1) Pajak daerah, yaitu iuran wajib yang dilakukan oleh orang pribadi atau badan kepada daerah tanpa imbalan langsung yang seimbang yang dapat membiayai penyelenggaraan pemerintah daerah dan pembangunan daerah (2) Retribusi Daerah, yaitu pungutan terhadap orangatau badan kepada pemerintah daerah dengan konsekuensi pemerintah daerah memberikan jasa pelayanan atau perijinan tertentu yang langsung dapat dirasakan oleh pembayar retribusi (3) Bagian Laba Badan Usaha Milik Daerah, merupakan bagian keuntungan atau laba bersih dari perusahaan daerah atas badan lain yang merupakan badan usaha milik daerah. Perusahaan daerah adalah perusahaan yang modalnya sebagian atau seluruhnya merupakan kekayaan daerah yang dipisahkan dan (4) Lain-lain Pendapatan Asli Daerah yang sah, merupakan penerimaan selain yang disebutkan butir 1,2, dan 3, tapi sah mencakup diantaranya : hasil penjualan kekayaan daerah yang tidak dipisahkan, hasil sewa tanah atau bangunan milik pemerintah daerah, pendapatan bunga, keuntungan selisih nilai tukar rupiah terhadap mata uang asing, ataupun bentuk lain sebagai akibat dari penjualan atau pengadaan barang dan jasa oleh daerah.

PAD dapat dimanfaatkan untuk biaya-biaya penyelenggaraan dan pembangunan daerah termasuk diantaranya wajib dialokasikan untuk pembangunan sarana dan prasarana yang diperlukan Wajib Pajak dan masyarakat, sehingga laju pertumbuhan ekonomi daerah dapat berdampak langsung terhadap besarnya PAD. Menurut Samsubar Saleh (2003), pendapatan daerah merupakan suatu komponen yang sangat menentukan berhasil tidaknya kemandirian pemerintah daerah dalam rangka otonomi daerahnya. Pendapatan Asli Daerah (PAD) merupakan salah satu sumber pendapatan daerah bagi anggaran pendapatan dan belanja daerah (APBD) yang sangat penting peningkatannya bagi pembangunan daerah. 


\section{National Conference of Creative Industry: \\ Sustainable Tourism Industry for Economic Development}

Universitas Bunda Mulia, Jakarta, 5-6 September 2018

e-ISSN No: 2622-7436

\section{Pengertian Pariwisata}

Menurut Institute of Tourism in Britain (Tourism Society in Britain) dalam Pendit (1999:30),'Pariwisata adalah kepergian orang-orang sementara dalam jangka waktu pendek ke tempat-tempat tujuan di luar tempat tinggal dan bekerja sehari-harinya serta kegiatan-kegiatan mereka selama berada di tempat- tempat tujuan tersebut: mencakup kegiatan untuk berbagai maksud, termasuk kunjungan seharian atau darmawisata/ekskursi". Menurut Undang-undang no 10 tahun 2009 tentang Kepariwisataan, definisi pariwisata adalah "Berbagai macam kegiatan wisata dan didukung fasilitas serta layanan yang disediakan masyarakat setempat, sesama wisatawan, pemerintah, pemerintah daerah dan pengusaha".

Berdasarkan motif tujuan perjalanan wisata, James J, Spillane (1987), mengelompokan jenis pariwisata sebagai berikut : (a). Pariwisata Untuk Menikmati Perjalanan (Pleasure Tourism) dilakukan untuk berlibur, mencari udara segar, memenuhi keingintahuan, mengendorkan ketegangan saraf, melihat sesuatu yang baru, menikmati keindahan alam, dan mendapatkan kedamaian. (b). Pariwisata Untuk Rekreasi (Recreation Tourism), dilakukan sebagai pemanfaatan hari-hari libur untuk beristirahat, memulihkan kesegaran jasmani dan rohani dan menyegarkan keletihan. (c). Pariwisata Untuk Kebudayaan (Cultural Tourism), ditandai serangkaian motivasi seperti keinginan belajar di pusat riset, mempelajari adat-istiadat, mengunjungi monumen bersejarah dan peninggalan purbakala, festival seni musik. (d). Pariwisata Untuk Olah Raga (Sports Tourism), (e). Pariwisata Untuk Urusan Usaha Dagang (Business Tourism) dan (f). Pariwisata untuk Berkonvensi (Convention Tourism).

Menurut UU RI No.10, tahun 2009 tentang Kepariwisataan pasal 14, bahwa Usaha Pariwisata meliputi : (1) daya Tarik Wisata, (2) Kawasan Pariwisata, (3) Jasa Transportasi Wisata, (4) Jasa Perjalanan Wisata , (5) Jasa makanan dan minuman, (6) Penyediaan Akomodasi, (7) Penyelenggaraan Kegiatan Hiburan dan Rekreasi, (8) Penyelenggaraan pertemuan, Perjalanan Insentif, Konferensi, dan Pameran (MICE), (9) Jasa Informasi Pariwisata, (10) Jasa Konsultan Pariwisata, (11) Jasa Pramu Wisata , (12) Wisata Tirta, (13) Spa.

\section{Konsep Pajak}

Menurut Soemitro dalam Ilyas dan Burton (2011:6), pajak adalah iuran rakyat kepada kas negara berdasarkan Undang-Undang (yang dapat dipaksakan) dengan tiada mendapat jasa-timbal (kontraprestasi), yang langsung dapat ditunjukan dan yang digunakan untuk membayar pengeluaran umum. Secaraumum pajak yang diberlakukan di Indonesia dapat dibedakan dengan klasifikasi sebagai berikut: (1) Menurut golongannya yaitu pajak langsung dan tidak langsung, (2) Menurut sifatnya yaitu pajak subyektif dan pajak obyektif, dan (3) Menurut lembaga pemungutnya yaitu pajak pusat dan pajak daerah (Mardiasmo, 2011). Masih menurut Mardiasmo (2006:5), Pajak Pusat adalah pajak yang dipungut oleh pemerintah pusat dan digunakan untuk membiayai rumah tangga negara, sedangkan Pajak Daerah adalah pajak yang dipungut oleh pemerintah daerah dan digunakan untuk membiayai rumah tangga daerah.

.Pengesahan Undang-undang no 28/2019 tentang Pajak Daerah dan Retribusi Daerah (UU PDRD), sangat mendukungsistemdesentralisasidan otonomi daerah karena terdapat perubahan kebijakan yang cukup fundamental dalam penataan kembali hubungan keuangan antara Pusat dan Daerah. Siahaan (2010:10) menyatakan bahwa Pajak Daerah merupakan pajak yang ditetapkan oleh Pemerintah Daerah dengan Peraturan Daerah (PERDA), yang wewenang pemungutannya dilaksanakan oleh 


\section{National Conference of Creative Industry: \\ Sustainable Tourism Industry for Economic Development}

Universitas Bunda Mulia, Jakarta, 5-6 September 2018 e-ISSN No: 2622-7436

pemerintah daerah dan hasilnya digunakan untuk membiayai pengeluaran pemerintah daerah dalam melaksanakan penyelenggaraan pemerintahan dan pembangunan di daerah. Jenis Pajak Kabupaten atau Kota yang dapat dipungut oleh Pemerintah Daerah sesuaiUU No. 34 Tahun 2000, yaitu Pajak Hotel, Pajak Restoran, Pajak Hiburan, Pajak Reklame, Pajak Penerangan Jalan, Pajak Pengambilan Bahan Galian Golongan dan Pajak Parkir.

\section{Pajak Hotel}

Menurut Undang-Undang Nomor 28/2009, Pajak Hotel adalah pajak atas pelayanan yang disediakan oleh hotel. Hotel adalah fasilitas penyedia jasa penginapan/peristirahatan termasuk jasa terkait lainnya dengan dipungut bayaran, yang mencakup juga motel, losmen, gubuk pariwisata, wisma pariwisata, pesanggrahan, rumah penginapan dan sejenisnya, serta rumah kos dengan jumlah kamar lebih dari 10 (sepuluh).

Menurut Peraturan Daerah Kota Bogor Nomor 12Tahun 2011 tentang Pajak Hotel, yang di maksud Objek Pajak adalah pelayanan yang disediakan oleh hotel dengan pembayaran termasuk jasa penunjang sebagai kelengkapan hotel yang sifatnya memberikan kemudahan dan kenyamanan termasuk fasilitas olah raga dan hiburan. Jasa penunjang adalah fasilitas telepon, faksimili, teleks, internet, foto kopi, pelayanan cuci, setrika,transportasi. Termasuk fasilitas olah raga dan hiburan, antara lain pusat kebugaran (fitness center), kolam renang, spa, tenis, karaoke, pub yangdisediakan atau dikelola hotel, serta jasa persewaan ruangan dan makan minum untuk kegiatan acara atau pertemuan di hotel dan fasilitas sejenis lainnya yang disediakan atau dikelola hotel.Tarif Pajak Hotel di Kota Bogor ditetapkan sebesar 10\% (sepuluh persen).

\section{Pajak Restoran}

Menurut Peraturan Daerah Kota Bogor Nomor 6 Tahun 2011, Pajak Restoran adalah pajak atas pelayanan yang disediakan oleh restoran. Sedangkan yang dimaksud dengan restoran adalah fasilitas penyedia makanan dan atau minuman dengan dipungut bayaran, yang mencakup juga rumah makan, kafetaria, kantin, warung, bar dan sejenisnya termasuk jasa boga/catering.

Objek Pajak restoran adalah pelayanan yang disediakan oleh restoran. Objek Pajak restoran meliputi pelayanan penjualan makanan dan atau minuman yang dikonsumsi oleh pembeli, baik dikonsumsi di tempat pelayanan maupun di tempat lain. Tidak termasuk objek pajak adalah pelayanan yang disediakan oleh restoran yang nilai penjualannya tidak melebihi Rp 7.500.000,00 (tujuh juta lima ratus ribu rupiah) dalam 1 (satu) bulan.Tarif Pajak Restoran Kota Bogor ditetapkan sebesar 10\% (sepuluh persen).

\section{Pajak Hiburan}

Pajak Hiburan adalah pajak yang dikenakan untuk setiap penyelenggaraan hiburan. Hiburan adalah semua jenis tontonan, pertunjukan, permainan, dan/atau keramaian yang dinikmati dengan dipungut bayaran. Harga Tanda Masuk yang selanjutnya disebut HTM adalah nilai jual yang tercantum pada tanda masuk yang harus dibayar oleh penonton atau pengunjung. Penonton atau pengunjung adalah setiap orang yang menghadiri suatuhiburan untuk melihat dan/atau mendengar atau menikmatinya atau menggunakan fasilitas yang disediakan oleh penyelenggara hiburan kecuali penyelenggara, karyawan, artis, dan petugas yang menghadiri untuk melakukan tugas pengawasan. Wajib Pajak yang selanjutnya disebut WP adalah orang pribadi atau badan 


\section{National Conference of Creative Industry: \\ Sustainable Tourism Industry for Economic Development}

Universitas Bunda Mulia, Jakarta, 5-6 September 2018 e-ISSN No: 2622-7436

yang menyelenggarakan hiburan, meliputi: tontonan film, pagelaran kesenian, musik, tari, dan/atau busana; kontes kecantikan, bina raga, dan sejenisnya; pameran; diskotik, karaoke, klub malam, dan sejenisnya;sirkus, akrobat, dan sulap;permainan bilyar, golf, dan boling; pacuan kuda, kendaraan bermotor, dan permainan ketangkasan; panti pijat, refleksi, mandi uap/spa, dan pusat kebugaran (fitness center); dan pertandingan olah raga kecuali Objek pertunjukan seni tradisional. Tarif pajak untuk penyelenggaraan hiburan di kota Bogor ditetapkan bervariasi mulai dari 5\% (contohnya pagelaran kesenian) hingga $75 \%$ (contohnya diskotik, pub) sesuai dengan jenis hiburannya (Peraturan Daerah Kota Bogor Nomor 11 Tahun 2011).

\section{Peranan dan Kontribusi Pariwisata Terhadap PAD}

Kontribusi berasal dari bahasa inggris yaitu contribute, contribution,maknanya adalah keikutsertaan, keterlibatan, melibatkan diri maupunsumbangan.Menurut Kamus Besar Bahasa Indonesia, pengertian kontribusi adalah sumbangan, sedangkan menurut kamus ekonomi (T.Guritno 1992: 76) kontribusi adalah segala sesuatu yang diberikan secara bersama sama dengan pihak lain untuk tujuan biaya, atau kerugian tertentu atau bersama. Sehingga kontribusi dalam penelitian ini dapat diartikan sebagai sumbangan yang diberikan oleh sektor Pariwisata terhadap Pendapatan Asli Daerah Kota Bogor. Kontribusi digunakan untuk mengetahui sejauh mana sektor pariwisata Kota Bogor khususnya dalam Pajak Hotel, Pajak Restoran dan Pajak Hiburan memberikan sumbangan dalam penerimaan PAD. Untuk mengetahui kontribusi dilakukan dengan membandingkan penerimaan pajak sektor pariwisata periode tertentu dengan penerimaan PAD periode tertentu pula. Semakin besar hasilnya berarti semakin besar pula peranan pajak daerahterhadap PAD, begitu pula sebaliknya jika hasil perbandingannya terlalu kecil berarti peranan pajak daerahterhadap PAD juga kecil (Mahmudi, 2010:145).

Tabel 3- Kriteria Kontribusi

\begin{tabular}{lc}
\hline \multicolumn{1}{c}{ Kontribusi (\%) } & Kriteria Kontribusi \\
$>50$ & Sangat Baik \\
$40,10-50,00$ & Baik \\
$30,10-40,00$ & Cukup Baik \\
$20,10-30,00$ & Sedang \\
$10,00-20,00$ & Kurang Baik \\
$<10$ & Sangat Kurang \\
\hline Sumber: Kepmendagri no.690.900.327, 1996
\end{tabular}

Banyak penelitian yang menyebutkan bahwa sektor pariwisata dapat memberikan berbagai manfaat.Roerkaerts dan Savat dalam Spillane(1987:138), mengungkapkan bahwa sektor pariwisata dapat memberikan manfaat : (a) menambah pemasukan dan pendapatan, baik untuk pemerintah daerah maupun masyarakatnya. Penambahan ini bisa dilihat dari meningkatnya pendapatan dari kegiatan usaha yang dilakukan masyarakat, berupa penginapan, restoran dan rumah makan, pramuwisata, hiburan, biro perjalanan dan penyediaan cinderamata. (b). menambah devisa negara,(c). membuka kesempatan kerja, (d). merangsang pertumbuhan kebudayaan asli, serta (e) menunjang gerak pembangunan daerah.Beberapa penelitian sebelumnya tentang kontribusi sektor pariwisata terhadap PAD di Indonesia menunjukan hasil yang beragam. Hasil penelitian Edward W. Memah (2013), menguraikan bahwa kontribusi Pajak Hotel dan Pajak Restoran pada tahun 2007-2011 memberikan kontribusi yang 
baik terhadap PAD Kota Semarang. Persentase kontribusi Pajak Hotel terbesar tahun 2010 sebesar 8,11\% dan kontribusi Pajak Restoran tertinggi tahun 2009 sebesar 24,47\% . Putu Intan Ni Luh dan Yuliartini Supadmi (2015), mengungkapkan rata-rata kontribusi pemungutan pajak hotel dan restoran pada PAD Kota Denpasar pada kurun waktu 20092013 adalah 32,27 \% dengan kategori cukup baik. Namun beberapa hasil penelitian berikut menunjukan rasio kontribusi sektor pariwisata terhadap PAD yang termasuk dalam kriteria Kurang. Hasil penelitian Roro Bella A.W. Prasetio. Putri, Srikandi Kumaji dan Agung Darono (2014), menguraikan bahwarata-rata kontribusi penerimaan Pajak Hotel terhadap PAD Kota Malang tahun 2006-2013 adalah sebesar 5,18\% atau berada pada kriteria sangat kurang, rata-rata kontribusi penerimaan Pajak Restoran terhadap PAD sebesar 10,36\% yaitu berada pada kriteria kurang dan rata-rata kontribusi penerimaan Pajak Hiburan adalah sebesar $1,77 \%$ atau berada pada kriteria sangat kurang. Hasil penelitian Ni Kadek Ari Riastini, Ni Kadek Sinarwati, I Putu Gede Diatmika (2017), menunjukkan bahwa rasio kontribusi Pajak Hotel dan Restoran terhadap PAD Kabupaten Bangli tahun 2011-2015, termasuk dalam kategori sangat kurang, dimana hasil analisis kontribusi terbesar yang dicapai yaitu tahun 2011 hanya sebesar $1,24 \%$. Hasil penelitian terdahulu tentang pengaruh Pajak usaha pariwisata terhadap PAD, didapat hasil bahwa Pajak Hotel dan Pajak Restoran secara parsiaI dan simultan berpengaruh positif dan signifikan terhadap Pendapatan Asli Daerah (Ni Nyoman Suartini \& Made Suyana Utama, 2013; Ni Luh Gde Ana Pertiwi, 2014; Ni Made Marita \&Ketut Alit Suardana, 2016). Namun hasil penemuan tersebut berbeda dengan penelitian yang dilakukan oleh Siti Rochimah, Kharis Raharjo \& Abrar Oemar (2015), yang mengutarakan bahwa Pajak Hotel dan Pajak Restoran tidak berpengaruh secara parsial terhadap PAD Kota dan provinsi Jawa Tengah periode 2007-2012. PenelitianVadia Vamiagustin, Suhadak \& Muhammad Saifi (2014) juga mengutarakan bahwa Pajak Hotel secara parsial tidak berpengaruh terhadap PAD Kota Batu 2010-2012.

\section{Rerangka Konseptual dan Hipotesis}

Penelitian ini mengkaji peranan ekonomis pariwisata Kota Bogor melalui Pajak Hotel, Pajak Restoran dan Pajak Hiburan terhadap PAD dan juga menguji apakah masing-masing variabel pajak tersebut memiliki pengaruh terhadap Pendapatan Asli Daerah Kota Bogor. Sehingga rerangka konseptual digambarkan sebagai berikut:

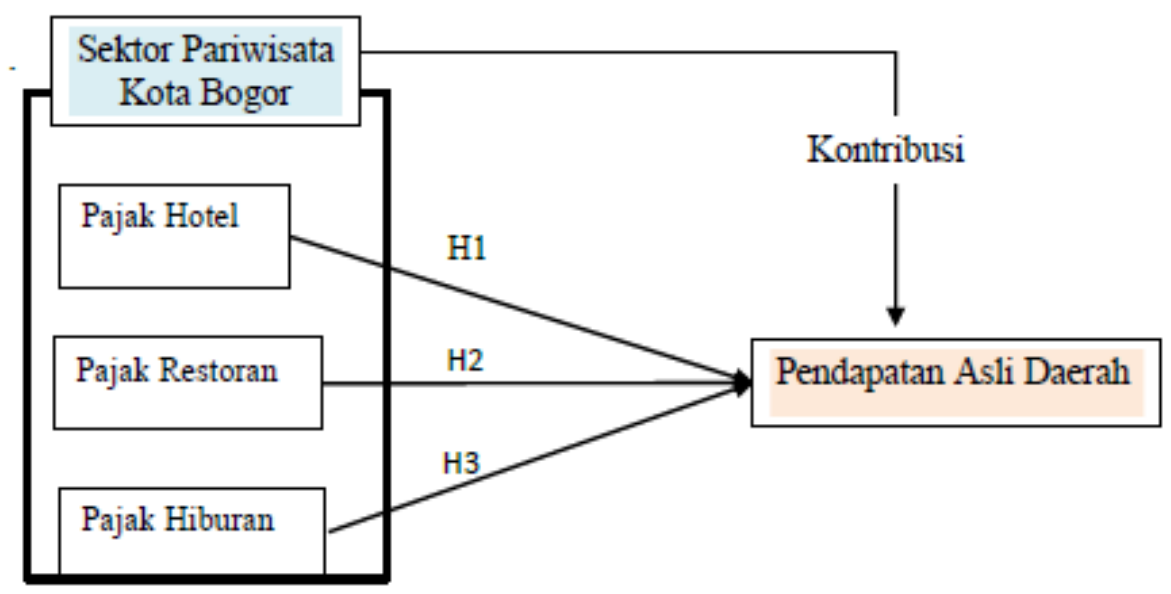

\section{Gambar 1. Rerangka Konseptual Penelitian}




\section{National Conference of Creative Industry: \\ Sustainable Tourism Industry for Economic Development}

Universitas Bunda Mulia, Jakarta, 5-6 September 2018 e-ISSN No: 2622-7436

Berdasarkan dari uraian pada latar belakang, tinjauan teori dan rerangka konseptual, berikut hipotesis yang digunakan dalam penelitian ini:

H1 : Pajak Hotel Kota Bogor secara parsial berpengaruh terhadap PAD

H2 : Pajak Restoran Kota Bogor secara parsial berpengaruh terhadap PAD

H3 : Pajak Hiburan Kota Bogor secara parsial berpengaruh terhadap PAD

\section{METODOLOGI PENELITIAN}

Penelitian ini menggunakan metode kuantitatif dengan teknik analisis regresi linear sederhana dan teknik analisis kontribusi. Objek penelitian adalah suatu atribut atau sifat atau nilai dari orang, objek atau kegiatan yang mempunyai variasi tertentu yang ditetapkan oleh peneliti untuk dipelajari dan kemudian ditarik kesimpulannya (Sugiyono, 2012:38). Objek penelitian yang digunakan dalam penelitian ini adalah Pendapatan Asli Daerah yang diperoleh dari Pajak Hotel, Pajak Restoran dan Pajak Hiburan pada kurun waktu tahun 2007 -2017. Teknik pengumpulan data melalui data sekunder yaitu dokumentasi data dari Badan Pendapatan Daerah dan Dinas Pariwisata Kota Bogor, serta studi literatur.

Uji Normalitas, Uji Autokorelasi dan Uji Heterokedatisitas dilakukan terlebih dahulu sebelum menerapkan uji regresi linear sederhana. Untuk menguji hipotesis dalam penelitian ini dilakukan dengan menggunakan Uji $t$ dan $\mathrm{Uji}^{2} \mathrm{R}^{2}$. Untuk mengetahui besar kontribusi Sektor Pariwista Kota Bogor terhadap PAD digunakan analisis kontribusi.Uji normalitas ini digunakan untuk mengetahui apakah data berdistribusi normal apa tidak. Uji Autokorelasimuncul karena observasi yang berurutan sepanjang waktu berkaitan satu sama lainnya. Masalah ini timbul karena residual (kesalahanpengganggu) tidak bebas dari satu observasi ke observasi lainnya. Hal ini sering ditemukan pada data runtut waktu (time series) "gangguan" pada seorang individu/kelompok cenderung mempengaruhi "gangguan" pada individu/kelompok yang sama pada periode berikutnya (Ghozali, 2011 :110). Untuk mendeteksi ada tidaknya autokorelasi dengan dilakukan uji Durbin-Watson. Uji heteroskedastisitas bertujuan untuk menguji apakah dalam model regresi terjadi ketidaksamaan variance dari residual satu pengamatan ke pengamatan lain (Ghozali, 2011:139). Jika variansi jawaban tetap, maka disebut homokedastisitas dan jika berbeda disebut heteroskedastisitas. Persamaan model regresi sederhana yang digunakan dalam penelitian ini adalah $\boldsymbol{Y}=\boldsymbol{a}+\mathbf{b X}(\mathrm{Y}=$ Pendapatan Asli Daerah , a= Konstanta, $\mathrm{b}=$ Koefisien regresi, $\mathrm{X}=$ Pajak Hotel / Pajak Restoran). Untuk menguji hipotesis dalam penelitian ini dilakukan dengan menggunakan Uji t dan Uji $\mathrm{R}^{2}$

\section{HASIL PENELITIAN DAN PEMBAHASAN}

Uji Normalitas

Tabel 4 - Tests of Normality

\begin{tabular}{lllllll}
\hline & \multicolumn{3}{l}{ Kolmogorov-Smirnova } & \multicolumn{3}{l}{ Shapiro-Wilk } \\
& \multicolumn{2}{l}{ Statistic } & df & Sig. & Statistic df & Sig. \\
PAD & .222 & 11 & .137 & .871 & 11 & .079 \\
Pajak Hotel & .184 & 11 & $.200^{*}$ & .889 & 11 & .136 \\
Pajak Restaurant & .183 & 11 & $.200^{*}$ & .904 & 11 & .205 \\
Pajak Hiburan & .169 & 11 & $.200^{*}$ & .949 & 11 & .627 \\
\hline
\end{tabular}

*. This is a lower bound of the true significance. 
a. Lilliefors Significance Correction

Berdasarkan Tabel 1 Test of Normality menggunakan Uji Kolmogorov-Smirnov terlihat nilai signifikansi pada seluruh variable memiliki nilai lebih dari 0.05 , sehingga dapat disimpulkan bahwa seluruh variabel berdistribusi normal.

Uji Autokorelasi

Tabel 5 - Uji Autokorelasi Pajak Hotel Model Summary ${ }^{b}$

\begin{tabular}{crrrrrl}
\hline Model & $\mathbf{R}$ & $\begin{array}{l}\text { R } \\
\text { Square }\end{array}$ & $\begin{array}{l}\text { Adjusted } \\
\text { Square }\end{array}$ & $\begin{array}{c}\text { Std. Error of the } \\
\text { Estimate }\end{array}$ & $\begin{array}{l}\text { Durbin- } \\
\text { Watson }\end{array}$ \\
1 & $.962^{\mathrm{a}}$ & .925 & .916 & 86693603909.483 & 1.484 \\
\hline
\end{tabular}

a. Predictors: (Constant), Pajak Hotel

b. Dependent Variable: Pendapatan Asli Daerah

Berdasarkan data Tabel 2 Model Summary diperoleh nilai Durbin-Watson dari hasil regresi adalah 1,484. Nilai dL dan dU berdasarkan table Durbin-Watson pada Signifikansi $0,05, \mathrm{n}=11$ dan $\mathrm{K}=1$ ( $\mathrm{n}$ adalah jumlah data dan $\mathrm{k}$ adalah jumlah variable independent). Didapat nilai $\mathrm{dL}=0,927$ dan $\mathrm{dU}=1,324$. Jadi dapat dihitung nilai $4-\mathrm{dU}=$ 2,676 dan $4-\mathrm{dL}=3.073$

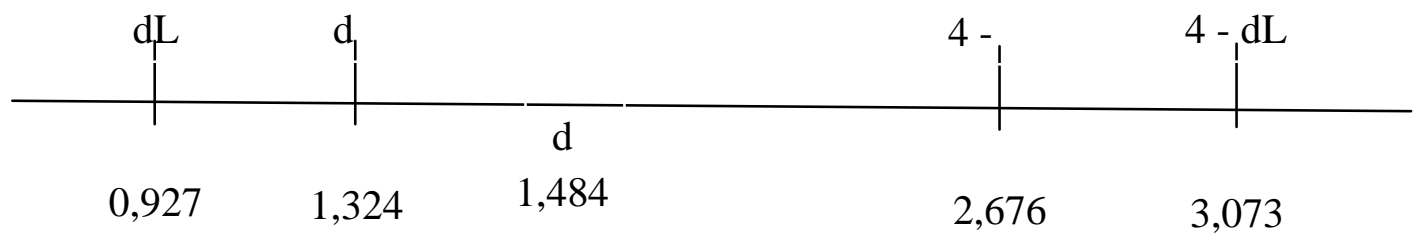

Dapat diketahui bahwa nilai d (Durbin-Watson) sebesar 1,484 terletak pada daerah dU < $\mathrm{d}<4-\mathrm{dU}(1,324<1,484<2,676$, maka tidak terjadi autokorelasi pada model regresi.

Tabel 6 - Uji Autokorelasi Pajak Restoran Model Summary ${ }^{b}$

\begin{tabular}{lccccc}
\hline Model & R & R Square & $\begin{array}{c}\text { Adjusted } \\
\text { R Square }\end{array}$ & $\begin{array}{c}\text { Std. Error of the } \\
\text { Estimate }\end{array}$ & Durbin-Watson \\
1 & $.988^{\mathrm{a}}$ & .977 & .974 & 47937716192.950 & 2.159 \\
\hline a. Predictors: (Constant), Pajak Restaurant \\
b. Dependent Variable: Pendapatan Asli Daerah
\end{tabular}

Berdasarkan Tabel 3. Model Summary Pajak Restoran diperoleh nilai DurbinWatson dari hasil regresi adalah 2,159. Nilai dL dan dU berdasarkan table DurbinWatson pada Signifikansi $0,05, \mathrm{n}=11$ dan $\mathrm{K}=1$ ( $\mathrm{n}$ adalah jumlah data dan $\mathrm{k}$ adalah jumlah variable independent). Didapat nilai $\mathrm{dL}=0,927$ dan $\mathrm{dU}=1,324$. Jadi dapat dihitung nilai 4-dU $=2,676$ dan 4-dL $=3.073$

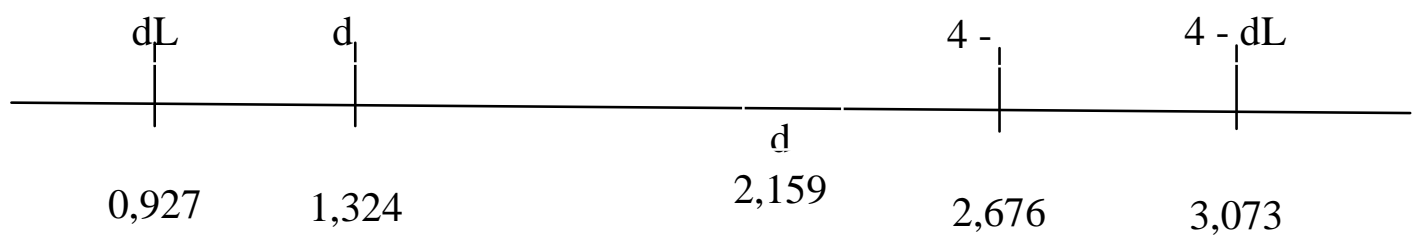


Dapat diketahui bahwa nilai d (Durbin-Watson) sebesar 2,159 terletak pada daerah dU < $\mathrm{d}<4-\mathrm{dU}(1,324<2,159<2,676$, maka tidak terjadi autokorelasi pada model regresi.

Tabel 7-Uji Autokorelasi Pajak Restoran Model Summary ${ }^{b}$

\begin{tabular}{cccccc}
\hline Model & R & R Square & $\begin{array}{c}\text { Adjusted R } \\
\text { Square }\end{array}$ & $\begin{array}{c}\text { Std. Error of the } \\
\text { Estimate }\end{array}$ & Durbin-Watson \\
1 & $.928^{\mathrm{a}}$ & .862 & .847 & 117203797903.641 & 1.151 \\
\hline
\end{tabular}

a. Predictors: (Constant), Pajak Hiburan

b. Dependent Variable: Pendapatan Asli Daerah

Berdasarkan data Model Summary Tabel 4, diperoleh nilai Durbin-Watson dari hasil regresi adalah 1,151. Nilai dL dan dU berdasarkan table Durbin-Watson pada Signifikansi $0,05, \mathrm{n}=11$ dan $\mathrm{K}=1$ ( $\mathrm{n}$ adalah jumlah data dan $\mathrm{k}$ adalah jumlah variable independent). Didapat nilai $\mathrm{dL}=0,927$ dan $\mathrm{dU}=1,324$. Jadi dapat dihitung nilai $4-\mathrm{dU}=$ 2,676 dan $4-\mathrm{dL}=3.073$

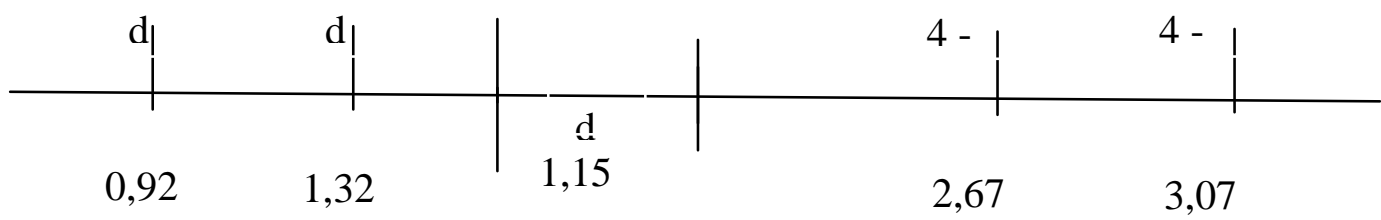

Dapat diketahui bahwa nilai d (Durbin-Watson) sebesar 2,159 terletak pada daerah dU < $\mathrm{d}<4-\mathrm{dU}(1,324<1,151<2,676$, maka tidak terjadi autokorelasi pada model regresi.

\section{Uji Heterokedastisitas}

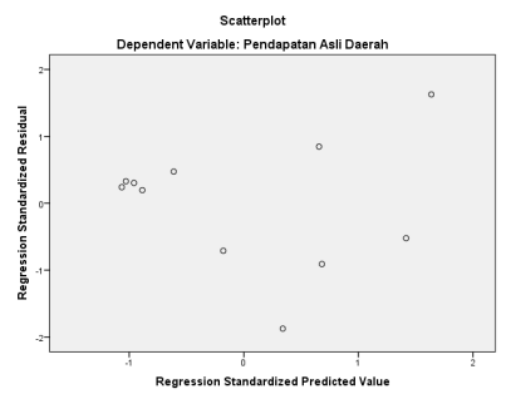

Gambar 2. Hasil Uji Heterokedastisitas Pajak Hotel

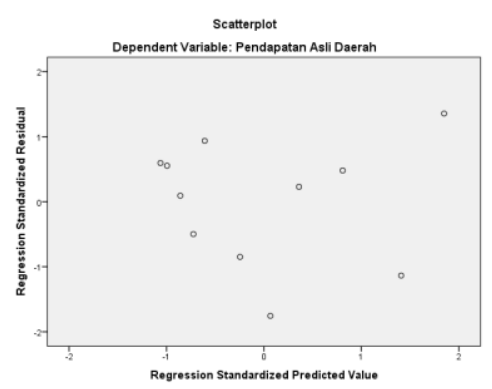

Gambar 3. Hasil Uji Heterokedastisitas Pajak Restoran 


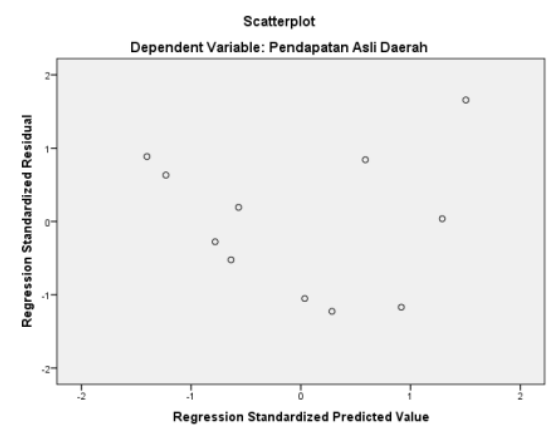

\section{Gambar 4. Hasil Uji Heterokedastisitas Pajak Hiburan}

Pola titik-titik pada scatterplot regresi menyebar dengan pola yang tidak jelas di atas dan di bawah angka 0 pada sumbu $\mathrm{Y}$ baik pada hasil uji Pajak Hotel, Pajak Restoran dan Pajak Hiburan, maka tidak terjadi masalah heterokedastisitas.

\section{Analisis Regresi Linier}

Persamaan regresi linier sederhana sebagai berikut:

$Y^{\prime}=b_{0}+b_{1} X$

Tabel 8- Pajak Hotel RegressionCoefficients ${ }^{a}$

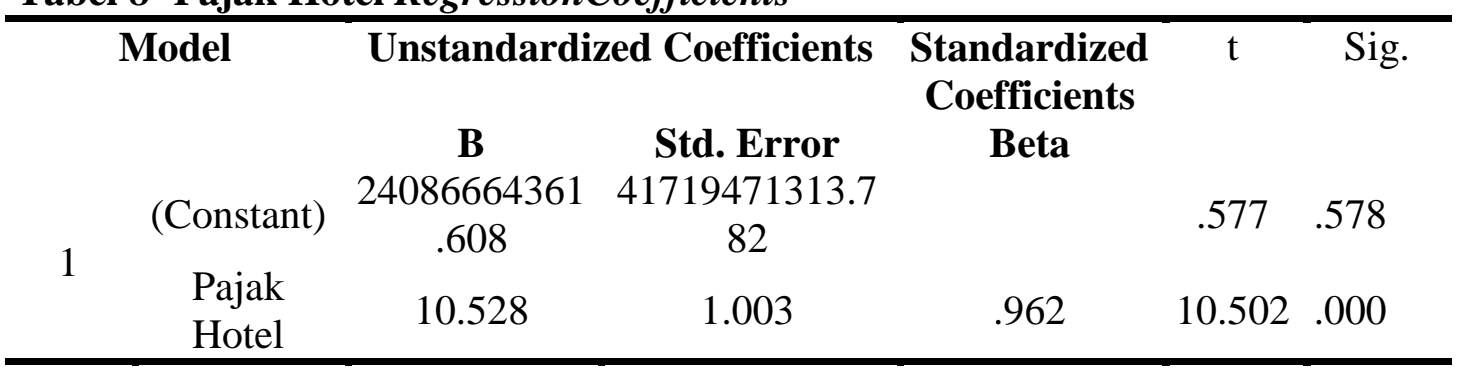

Sumber : Hasil olah data menggunakan SPSS 16

Persamaan Regresi untuk Pajak Hotel terhadap PAD adalah :

$Y^{\prime}=2,40867 E 10+10,528 X$

Tabel 9 - Pajak Restoran Regression Coefficients ${ }^{a}$

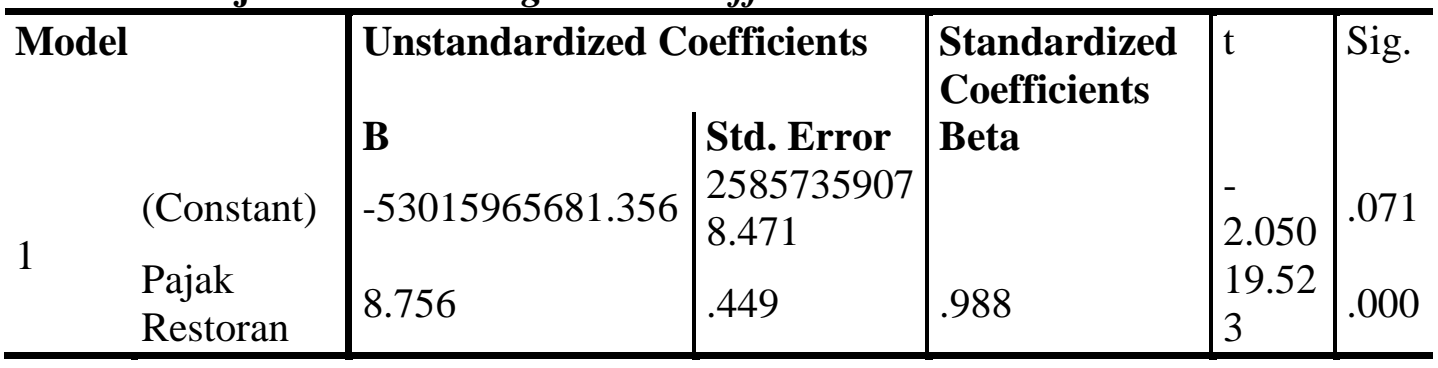

Sumber : Hasil olah data menggunakan SPSS 16 
Persamaan Regresi untuk Pajak Rstoran terhadap PAD adalah sebagai berikut :

Pajak Hiburan $Y^{\prime}=-5,3016 E 10+8,756 X$

Tabel 10- Pajak HiburanRegressionCoefficients ${ }^{a}$

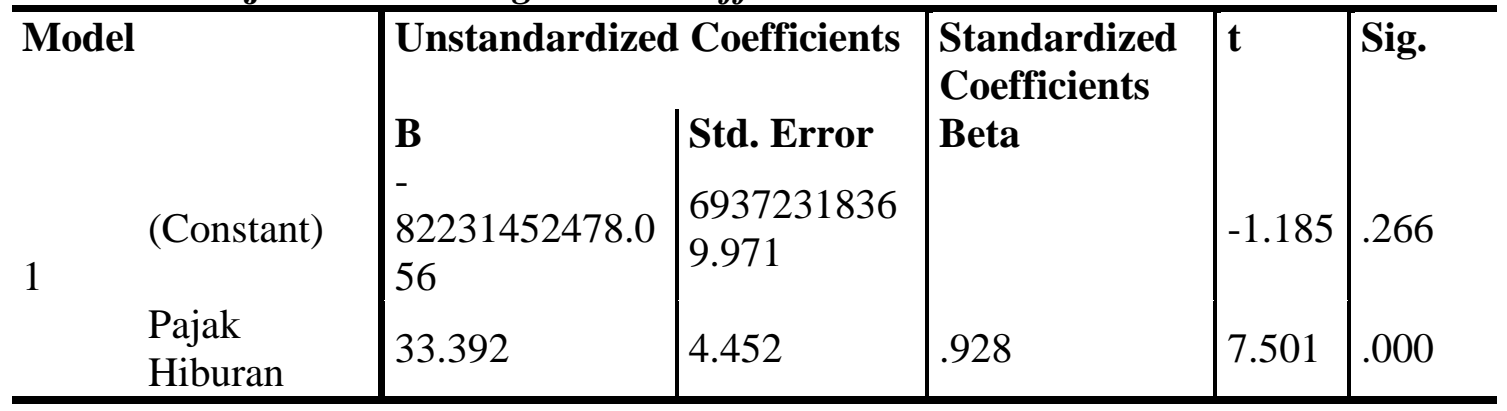

Sumber : Hasil olah data menggunakan SPSS 16

Persamaan regresi untuk Pajak Hiburan terhadap PAD adalah :

$Y^{\prime}=-8,2231 E 10+4,452 X$

Uji t-statistik

- $\mathrm{t}$ hitung berdasarkan table coefficients diatas adalah

○ Variabel Hotel $=10,502$

○ Variabel Restoran $=19,523$

○ Variabel Hiburan $=7,501$

- $t$ kritis dapat dicari pada table t statistic pada signifikansi 0,05/2 $=0,025$ (uji 2 sisi) dengan $\mathrm{df}=\mathrm{n}-\mathrm{k}-1$.

$\circ \mathrm{df}=10-1-1=8$. Di dapat t kritis adalah 2,306004.

Hasil Uji t-statistik berdasarkan tabel Coefficients $^{a}$

i) Pajak Hotel mempunyai $t_{\text {hitung }}>t_{\text {kritis }}(10,502>2,306004)$, sehingga Pajak Hotel berpengaruh signifikan terhadap Pendapatan Asli Daerah.

ii) Pajak Restoran mempunyai $t_{\text {hitung }}>t_{\text {kritis }}(19,523>2,306004)$, sehingga Pajak Restoran berpengaruh signifikan terhadap pendapatan asli daerah.

iii) Pajak Hiburan mempunyai $t_{\text {hitung }}>t_{\text {kritis }}(7,501>2,306004$, sehingga Pajak Hiburan berpengaruh terhadap pendapatan asli daerah.

$\mathbf{U j i} \mathbf{R}^{2}$

Tabel 11 - Hasil Uji R ${ }^{2}$ Pajak Hotel Terhadap PAD Model Summary ${ }^{b}$

\begin{tabular}{cccccc}
\hline Model & R & R Square & $\begin{array}{c}\text { Adjusted R } \\
\text { Square }\end{array}$ & $\begin{array}{c}\text { Std. Error of } \\
\text { the Estimate }\end{array}$ & $\begin{array}{c}\text { Durbin- } \\
\text { Watson }\end{array}$ \\
1 & $.961^{\mathrm{a}}$ & .924 & .915 & $\begin{array}{c}67659698406 \\
.716\end{array}$ & 1.530 \\
\hline
\end{tabular}

Sumber : Hasil olah data menggunakan SPSS 16

Dari data tabel 11, dapat diketahui angka $\mathrm{R}$ sebesar 0,961 yang menunjukkan bahwa korelasi atau hubungan variabel Pajak Restoran terhadap Pendapatan Asli Daerah Kota Bogor adalah kuat karena angka ini berada di atas 0,5. Angka adjusted $\mathrm{R}^{2}$ menunjukkan bahwa koefisien determinasi sebesar 0,915 atau 91,5\%, sehingga dapat 
dikatakan bahwa besarnya pengaruh variabel Pajak Restoran terhadap Pendapatan Asli Daerah Kota Bogor adalah sebesar $91,5 \%$ sedangkan sisanya 0,085 atau 8,5\% dipengaruhi oleh variabel lain diluar penelitian.

Tabel 12 - Hasil Uji R ${ }^{2}$ Pajak Restoran Terhadap PAD Model Summary ${ }^{b}$

\begin{tabular}{c|c|c|c|c|c}
\hline Model & $\mathbf{R}$ & $\begin{array}{c}\text { R } \\
\text { Square } \\
1\end{array}$ & $\begin{array}{c}\text { Adjusted } \\
\text { R Square } \\
.988^{\mathrm{a}}\end{array}$ & $\begin{array}{c}\text { Std. Error of the } \\
\text { Estimate } \\
.977\end{array}$ & $\begin{array}{c}\text { Durbin- } \\
\text { Watson }\end{array}$ \\
\hline
\end{tabular}

Sumber : Hasil olah data menggunakan SPSS 16

Dari data tabel 12, dapat diketahui angka $\mathrm{R}$ sebesar 0,988 yang menunjukkan bahwa korelasi atau hubungan variabel pajak restoran terhadap pendapatan asli daerah kota bogor adalah kuat karena angka ini berada diatas 0,5. Kemudian untuk angka adjusted $\mathrm{R}^{2}$ menunjukkan bahwa koefisien determinasi sebesar 0,974 atau 97,4\%. Dengan demikian dapat dikatakan bahwa besarnya pengaruh variabel Pajak Restoran terhadap Pendapatan Asli Daerah Kota Bogor adalah sebesar 97,4\% sedangkan sisanya 0,026 atau 2,6\% dipengaruhi oleh variabel lain diluar penelitian.

Tabel 13 -Hasil Uji R ${ }^{2}$ Pajak Hiburan Terhadap PAD Model Summary ${ }^{b}$

\begin{tabular}{l|l|l|l|l|l}
\hline Model & $\mathbf{R}$ & $\begin{array}{l}\mathbf{R} \\
\text { Square }\end{array}$ & $\begin{array}{l}\text { Adjusted } \\
\text { R Square }\end{array}$ & $\begin{array}{l}\text { Std. Error of } \\
\text { the Estimate } \\
117203797903.6 \\
1\end{array}$ & $\begin{array}{l}\text { Durbin- } \\
\text { Watson }\end{array}$ \\
\hline
\end{tabular}

Sumber : Hasil olah data menggunakan SPSS 16

Dari data tabel 13 dapat diketahui angka $\mathrm{R}$ sebesar 0,928 yang menunjukkan bahwa korelasi atau hubungan variabel Pajak Hiburan terhadap Pendapatan Asli Daerah Kota Bogor adalah kuat karena angka ini berada di atas 0,5. Angka adjusted $\mathrm{R}^{2}$ menunjukkan bahwa koefisien determinasi sebesar 0,847 atau $84,7 \%$ sehingga dapat dikatakan bahwa besarnya pengaruh variabel Pajak Restoran terhadap Pendapatan Asli Daerah Kota Bogor adalah sebesar $84,7 \%$ sedangkan sisanya 0,153 atau $15,3 \%$ dipengaruhi oleh variabel lain di luar penelitian.

\section{Kontribusi Pajak Pariwisata Terhadap Pendapatan Asli Daerah}

Tabel 14 - Rasio Kontribusi

\begin{tabular}{ccccc}
\hline Tahun & $\begin{array}{c}\text { Pajak Pariwisata Kota }- \\
\text { Bogor (Hotel, Restoran, } \\
\text { dan Hiburan) }\end{array}$ & $\begin{array}{c}\text { Pendapatan } \\
\text { Asli Daerah } \\
\text { (PAD) }\end{array}$ & $\begin{array}{c}\text { Rasio } \\
\text { Kontribusi } \\
(\boldsymbol{\%})\end{array}$ & $\begin{array}{c}\text { Kriteria } \\
\text { Kontribusi }\end{array}$ \\
2007 & $16,936,027,163$ & $79,659,761,934$ & 21.26 & Sedang \\
2008 & $21,647,279,303$ & $97,730,780,727$ & 22.15 & Sedang \\
2009 & $31,926,396,063$ & $115,921,660,827$ & 27.54 & Sedang \\
\hline
\end{tabular}




\begin{tabular}{lllll}
2010 & $39,666,921,024$ & $127,488,089,831$ & 31.11 & Cukup Baik \\
2011 & $51,643,203,834$ & $230,449,644,620$ & 22.41 & Sedang \\
2012 & $80,746,878,495$ & $252,280,722,686$ & 32.01 & Cukup Baik \\
2013 & $107,539,226,957$ & $300,932,470,210$ & 35.74 & Cukup Baik \\
2014 & $132,069,964,887$ & $483,014,420,704$ & 27.34 & Sedang \\
2015 & $143,810,746,945$ & $627,815,080,243$ & 22.91 & Sedang \\
2016 & $190,714,901,770$ & $728,030,823,933$ & 26.20 & Sedang \\
2017 & $213,430,339,141$ & $977,803,906,993$ & 21.83 & Sedang \\
Total & $1,030,131,885,582$ & $4,021,127,362,708$ & $\mathbf{2 5 . 6 2}$ & Sedang \\
\hline
\end{tabular}

Sumber : Hasil olah data menggunakan rasio kontribusi

Sesuai data Tabel 14, secara nominal, realisasi penerimaan Pajak Pariwisata Kota Bogor (Hotel, Restoran dan Hiburan) terhadap PAD Kota Bogor dalam kurun waktu 11 tahun terakhir (2007-2017), terus mengalami pertumbuhan. Pada tahun 2013, rasio kontribusi sektor pariwisata dari penerimaan Pajak Pariwisata Kota Bogor terhadap PAD mencapai angka tertinggi yaitu 34,74 \% sehingga bisa dikategorikan Cukup Baik. Kontribusi Pajak Pariwisata Kota Bogor mencapai rasio terendah di tahun 2007 yaitu sebesar 21,26 \% sehingga masuk dalam kriteria Sedang. Rata-rata rasio kontribusi pajak sektor pariwisata Kota Bogor tahun 2007 hingga 2017 adalah 25,62 \% atau termasuk dalam kriteria Kontribusi Sedang.

\section{KESIMPULAN DAN IMPLIKASI}

Berdasarkan hasil dan pembahasan yang telah dilakukan maka dapat disimpulkan bahwa:

1. Pajak Hotel memiliki pengaruh secara positif dan signifikan terhadap Pendapatan Asli Daerah Kota Bogor pada tahun 2007-2016, hal ini dapat ditunjukkan dengan Pajak Hotel mempunyai $t_{\text {hitung }}>t_{\text {kritis }}(-10,502>2,306004)$, maka $\mathrm{H}_{0}$ ditolak. Sehingga dapat disimpulkan bahwa Pajak Hotel Kota Bogor berpengaruh terhadap Pendapatan Asli Daerah.

2. Pajak Restoran memiliki pengaruh secara positif dan signifikan terhadap Pendapatan Asli Daerah Kota Bogor pada tahun 2007-2016, hal ini dapat ditunjukkan dengan Pajak Restoran mempunyai $t_{\text {hitung }}>t_{\text {kritis }}(19,523>$ 2,306004), maka $\mathrm{H}_{0}$ ditolak (Pajak Restoran tidak berpengaruh terhadap Pendapatan Asli Daerah-ditolak), sehingga dapat disimpulkan bahwa Pajak Restoran Kota Bogor berpengaruh terhadap Pendapatan Asli Daerah.

3. Pajak Hiburan memiliki pengaruh secara positif dan signifikan terhadap Pendapatan Asli Daerah Kota Bogor pada tahun 2007-2016, hal ini dapat ditunjukkan dengan Pajak Restoran mempunyai $t_{\text {hitung }}>t_{\text {kritis }}(7,501>2,306004)$, 


\section{National Conference of Creative Industry: \\ Sustainable Tourism Industry for Economic Development}

Universitas Bunda Mulia, Jakarta, 5-6 September 2018 e-ISSN No: 2622-7436

maka $\mathrm{H}_{0}$ ditolak (Pajak Hiburan tidak berpengaruh terhadap Pendapatan Asli Daerah-ditolak), sehingga dapat disimpulkan bahwa Pajak Hiburan Kota Bogor berpengaruh terhadap Pendapatan Asli Daerah.

4. Pajak sektor pariwisata Kota Bogor (Hotel, Restoran dan Hiburan) memiliki pengaruh positip yang signifikan terhadap Pendapatan Asli Daerah, akan tetapi Pajak Restoran lebih memberikan pengaruh yang dominan dibandingkan dengan Pajak Hotel dan Pajak Hiburan. Hal ini dapat dilihat dari nilai Adjusted $\mathrm{R}^{2}$ masing-masing variabel.

5. Kontribusi pajak sektor pariwisata Kota Bogor dari usaha hotel, restoran dan hiburan, untuk kurun waktu 2007-2017 memberikan peranan ekonomis dalam nominal sejumlah Rp. 1,030,131,885,582 atau sebesar25,62 \% terhadap PAD sehingga termasuk dalam kriteria sedang atau bisa dikatakan mempunyai peranan sedang terhadap PAD.

Pemerintah dapat meningkatkan dukungan dan kerjasama dengan swasta dan masyarakat pariwisata agar tercipta iklim usaha yang kondusif bagi pariwisata Kota Bogor. Untuk selanjutnya perlu dilakukan kajian lebih lanjut tentang peranan pemerintah dalam meningkatkan kualitas pariwisata Kota Bogor sehingga dapat menunjang terciptanya pariwisata kota yang berdaya saing dan sustainable, juga dapat meningkatkan peranannya bagi pembangunan daerah.

\section{DAFTAR PUSTAKA}

Badrudin, Rudi.(2001). Menggali Sumber Pendapatan Asli Daerah (PAD) Daerah Istimewa. Yogyakarta Melalui Pembangunan Industri Pariwisata. Jurnal Kompak, 3, 384-403.

Departemen Pendidikan Dan Kebudayaan. (2005). Kamus Besar Bahasa Indonesia. Jakarta: Balai Pustaka.

Dinas Pariwisata dan Kebudayaan Kota Bogor. (2017). Data Pariwisata Kota Bogor Jilid 1. Bogor.

Ghozali, Imam. (2011). Aplikasi Analisis multivariate Dengan Program IBM SPSS 19 (edisi ke 5). Semarang : Universitas Diponegoro.

Guritno,T. (1992).Kamus Ekonomi. Yogyakarta: Universitas Gadjah Mada, Press.

Ilyas,W. dan Burton, R. (2011). Hukum Pajak. Jakarta: Salemba Empat.

Keputusan Menteri Perdagangan Dalam Negeri No.690.900.327. (1994). Pedoman Pengelolaan Keuangan Daerah.

Mahmudi. (2010).Analisis Laporan Keuangan Pemerintah Daerah. Yogyakarta :Sekolah Tinggi Ilmu Manajemen. 


\section{National Conference of Creative Industry: \\ Sustainable Tourism Industry for Economic Development}

Universitas Bunda Mulia, Jakarta, 5-6 September 2018 e-ISSN No: 2622-7436

Mardiasmo. (2011).Perpajakan, Edisi Revisi. Yogyakarta: Andi.

Mardiasmo. (2006). Otonomi dan Manajenem Keuangan Daerah, Edisi Revisi.Yogyakarta: Andi.

Memah, Edward W. (2013). Efektivitas Dan Kontribusi Penerimaan Pajak Hotel dan Restoran Terhadap PAD Kota Manado. Jurnal EMBA, 1 No 3, 871-881.

Pendit, Nyoman. (1999). Ilmu Pariwisata. Jakarta: Akademi Pariwisata Trisakti.

Peraturan Daerah Kota Bogor Nomor 6. (2011). Pajak Hiburan.

Peraturan Daerah Kota Bogor Nomor 11. (2011). Pajak Restoran.

Peraturan Daerah Kota Bogor Nomor 12. (2011). Pajak Hotel.

Pertiwi.Ni Luh Gde Ana.(2014).Pengaruh Kunjungan Wisatawan, Retribusi Objek Wisata dan PHR terhadap PAD Kabupaten Gianyar, E-Jurnal Ekonomi Pembangunan, UniversitasUdayana. 3.3.

Prasetio Putri, Roro Bella Ayu., Kumadji, Srikandi., dan Darono, Agung. (2014). Analisis Penerimaan Pajak Hotel, Pajak Restoran Pajak Hiburan Sebagai Sumber PAD (Studi Pada Dinas Pendapatan Daerah Kota Malang).Jurnal Perpajakan Universitas Brawijaya.3.1.

Rencana Induk Pengembangan Pariwisata Daerah Kota Bogor (RIPPARDA) 20162025. 2016. Diakses pada 13 Juli 2018, dari https://www.scribd.com/document/100822768/Bab-1-Pendahuluan-Bogor020711

Rochimah,Siti \&Raharjo Kharis dan Oemar, Abrar.(2015).Pengaruh Pajak Hotel dan Restoran, Retribusi Dan Pajak Daerah Terhadap PAD Pada Kabupaten/Kota Provinsi Jawa Tengah Tahun 2007-2012.Tesis

Samsubar,Saleh. (2003). Kemampuan Pinjam Daerah Kabupaten dan Kota di Indonesia. Jurnal Media Ekonomi \& Bisnis, XIV, 2.

Siahaan, Marihot P. (2010). Pajak Daerah dan Retribusi Daerah Edisi Revisi.Jakarta: PT Rajagrafindo Persada.

Soeswoyo, Dina M. (2018). Efektivitas dan Kontribusi Pariwisata Kota Bogor terhadap Pendapatan Asli Daerah. Tourism Scientific Journal STIEPAR YAPARI.3.2

Sugiyono.(2012).Metode Penelitian Kuantitatif Kualitatif dan R\&D. Bandung: Alfabeta

Suartini, Ni Nyoman \& Utama, Made Suyana.(2013).Pengaruh Jumlah Kunjungan Wisatawan Pajak Hiburan, Pajak Hotel dan Pajak Restoran Terhadap PAD Kabupaten Gianyar. 
Spillane, James J. (1987). Pariwisata Indonesia. Yogyakarta: Kanisius.

Republik Indonesia. Undang-Undang Nomor 28. (2009). Pajak Daerah dan Retribusi Daerah.

Republik Indonesia. Undang-Undang Nomor 34. (2000). Jenis dan Tarif Pajak Kabupaten atau Kota.

Riastiani, Ni Kadek Ari., Sinarwati,Ni Kadek., dan Diatmika, I Putu Gede. (2017).Efektivitas Dan Kontribusi Pajak Hotel Dan Restoran Di Kintamani Terhadap Pendapatan Asli Daerah Kabupaten Bangli Tahun 2011-2015. EJournal S1 Ak Universitas Pendidikan Ganesha.8. 2.

Vamiagustin, Vadia dan Saifi,Suhadak Muhammad.(2014). Pengaruh Pajak Daerah Terhadap PAD(Studi Kasus Pada Dinas Pendapatan Kota Batu Tahun 2010 2012) Jurnal Administrasi Bisnis (JAB). 4.2

Wahab, Salah. (2006). Manajemen Kepariwisataan. Jakarta: PT. Pradnya Paramita

Yahya, Arief. (2018). Pariwisata Era Digital. Seminar Nasional Pariwisata. 2018. Jakarta, Indonesia

\section{BIODATA}

Dina Mayasari adalah Magister Pariwisata lulusan Sekolah Tinggi Pariwisata Trisakti Jakarta yang kemudian sejak 2015 menjadi salah satu dosen Program Studi Diploma Empat Perhotelan Sekolah Tinggi Pariwisata Bogor.Berpengalaman lebih dari 10 tahun sebagai praktisi di industri hotel, restoran dan hiburan. Tertarik melakukan penelitian bidang pemasaran pariwisata, manajemen destinasi pariwisata, SDM pariwisata serta budaya.

Sekti Rahardjo adalah dosen tetap di Sekolah Tinggi Pariwisata Bogor. Lulus dari IPB sebagai Sarjana Teknologi Pertanian kemudian melanjutkan studi dan berhasil meraih gelar Magister Manajemen. Tertarik melakukan penelitian di bidang manajemen dan ekonomi. 